\title{
A JAVÍTÓINTÉZETI NEVELÉS KOMPLEXITÁSA A KRIMINÁLPEDAGÓGIA TÜKRÉBEN
}

\section{Szerző:}

Molnár Fanni

Debreceni Egyetem

Szerző e-mail címe:

molnarfannii97@gmail.com

\section{Lektorok:}

\author{
Mező Ferenc $(\mathrm{PhD})$ \\ Eszterházy Károly Egyetem \\ Mező Katalin (PhD) \\ Debreceni Egyetem
}

és további két anonim lektor...

\section{Absztrakt}

E tanulmány a javítóintézeti nevelés (jeleneteit, oktatóit) vizsgálja a kriminálpedagógia tükrében. Ebben a cikkben egy folyamat közbeni kvalitatív kutatás is bemutatásra kerül, amely a javítóintézeti nevelés oktatási folyamatát vizsgálja. A tanulmány tartalmazza a kutatás kriminálpedagógiai alapjait.

Kulcsszavak: javítóintézet, kriminálpedagógia, nevelés, szociálpedagógia

Diszciplina: pedagógia

\begin{abstract}
COMPLEX EDUCATION IN REFORMATORY IN LIGHT OF CRIMINAL PEDAGOGY

This study investigates reformatory education (its scenes, educators) in light of criminal pedagogy. In this article, in-process qualitative research is also shown that investigates the process of education of reformatory. This article contains the criminal pedagogy underlies of the research.
\end{abstract}

Keywords: reformatory, criminal pedagogy, education, social pedagogy

Discipline: pedagogy

Molnár Fanni (2021): A javítóintézeti nevelés komplexitása a kriminálpedagógia tükrében. OxIPO folyóirat, 2021/2. szám, 65-75. DOI: 10.35405/OXIPO.2021.2.65 
A tanulmányban a különböző kriminálpedagógiai elméleteket a javítóintézeti nevelésre vonatkoztatva vizsgáljuk. A gyermekek védelmérōl és a gyámügyi igazgatásról szóló 1997. évi XXXI. törvény (továbbiakban: Gyvt.) 15. § (5) bekezdése szerint a javítóintézeti nevelés a gyermekvédelmi jelzőrendszer része. A büntetések, az intézkedések, egyes kényszerintézkedések és a szabálysértési elzárás végrehajtásáról szóló 2013. évi CCXL. törvény 344. §-a deklarálja a javítóintézeti nevelés célját, miszerint az intézkedés végrehajtása során elő kell segíteni a fiatalkorú társadalmi beilleszkedését, aminek érdekében szükségszerű enyhíteni a beilleszkedési zavarait, rendezni pszichés állapotát, növelni iskolázottságát, illetve elfogadtatni az alapvető erkölcsi normákat, továbbá elősegíteni az egészséges életmód kialakítását.

Ez alapján látható, hogy a javítóintézetek elsődleges célja az, hogy a fiatalkorút hozzásegítse az erkölcsös magatartás gyakorlásához, a társadalomba való reintegrációhoz, tehát nem büntetésrôl beszélünk, hanem sokkal inkább korrekcióról, illetve tercier prevencióról, mivel az elsődleges cél az, hogy a fiatalkorú ne kövessen el újabb bűncselekményt. Ebből adódóan a javítóintézeti nevelés egyszerre végez preventív és korrektív tevékenységet.

A növendékekkel foglalkozó szakemberek saját területük kompetenciáira támaszkodva közösen végzik a komplex nevelési feladatokat, amihez elengedhetetlenül fontosak többek között a kriminálpedagógiai ismeretek.

A kriminálpedagógia a pedagógia egy részterülete, ami a bűnelkövetôk zárt intézeti nevelésével foglalkozik. A kriminálpedagógia egyik fontos alapját a kriminológiai kutatások képezik, amiken keresztül megfogalmazódnak a nevelési programok (Korinek és Lévay, 2006). A kriminálpedagógia nem függetleníthetô más társtudományoktól, azoknak a rendszerében fogalmazódnak meg a nevelési elvek. Ilyen társtudomány a pedagógia azon belül az általános pedagógia, szociálpedagógia, gyógypedagógia, továbbá a pszichológia azon belül a szociálpszichológia, illetve szociológia és kriminológia (Ruzsonyi, 2006). Ezeket alapul véve láthatóvá válik, hogy a kriminálpedagógiát egy multidiszciplináris térben szükséges értelmeznünk. A továbbiakban áttekintésre kerülnek azok a neveléselméletek, amik a kriminálpedagógia részét képzik, illetve kifejtésre kerül, hogy a kriminálpedagógia alapelvei hogyan jelennek meg a javítóintézeti nevelés struktúrájában, végül szeretném bemutatni a jelenleg folyamatban lévő kutatásunk hátterét, ami a javítóintézeti nevelés folyamatára fókuszál.

\section{A javítóintézeti nevelés során alkalmazható kriminálpedagógiai elméletek}

A javítóintézeti nevelés eredményes végrehajtásával kapcsolatban több elméleti megközelítés született. Volentics 
(1996) modellje elsődlegesen pszichológiai megalapozottságú, amely a szükségletekre orientált. Volentics (1996) szerint a zárt intézetnek a következő szükségletekből célszerű kiindulnia: mentálhigiénés, szociális jellegű, egészségügyi, illetve nevelésioktatási szükségletek. Szerinte az intézeti nevelés célja, hogy kialakítsák az igényt ezekre a szükségletekre, illetve diszfunkció esetén korrigálják azt. A komplex fejlesztés során a különböző részterületekhez problémaprofil elkészítését javasolja, amely lehetőséget nyújt arra, hogy minden növendék esetén a nevelés az egyéni szükségletekre fókuszáljon (Volentics, 1996). A szerző a javítóintézeti reszocializáció eredményességének érdekében kutatására alapozva további javaslatokat fogalmazott meg, amelyek a következők: kulturáltsági szint emelése, a szocializációs folyamat hiányosságainak pótlása, munkavégzéshez szükséges képességek fejlesztés, viselkedés-magatartás formálása, érzelmi élet fejlesztése, „erkölcsi struktúrák” javítása, családi és baráti kapcsolatok rendezése, formálása. Volentics (1994) kiemeli az egyéniesítés fontosságát, mivel csak a személyre szabott nevelési terv tudja biztosítani a fiatal számára azt, hogy a személyisége pozitív irányba változzon (Volentics, 1994).

Ruzsonyi (2008) szerint a zárt intézetben megvalósuló kriminálpedagógiai nevelés nem cél, hanem a cél eléréséhez szükséges eszköz. A nevelési közeg külső kényszer eredményeként alakul ki, és az érintettek bizonyos jogainak korlátozása mellett zajlik. Ruzsonyi (2008) szerint a cél - aminek eszköze a nevelés - a konstruktív életvezetés megalapozása kriminális magatartást tanúsító bűnelkövetők körében (Ruzsonyi, 2008). A pedagógiai személyiségfejlesztési felfogását a Bábosik (1987) által kidolgozott rendszerre és a Maslow (1970) szükséglethierarchiai biztonság és szeretet szükségletekre, illetve a megismerő-szociális kompetenciára alapozza. Szerinte szükségszerű, hogy a korrektív nevelés során a kognitív és szociális készségeket együtt fejlesszék. Ruzsonyi (2002) szerint egyes területek formálására pedagógiai megközelítésből bármely zárt intézetben lehetőség van. A kognitívszociális kompetenciák részét képezik a konfliktuskezelés és a praktikus életismeretek átadása. Ezek mellett Volenticshoz (1994) hasonlóan további nevelési részterületeket jelöl meg, amelyek a következők: helyes szokások kialakítása, példakép formálása, egészséges életmódra való igény kialakítása, biztonságra-elfogadásra való igény kialakítása, készségek fejlesztése, ismeretek közvetítése (Ruzsonyi, 2002).

A továbbiakban ismertetésre kerül Bronfenbrenner (1992) modellje, ami a javítóintézeti növendékek szocializációs folyamatára is vonatkoztatható. Bronfenbrenner (1992) ökológiai modelljében tekintettel a szocializációs folyamatra négy rendszert különböztet meg, amelyek a következők: mikro-, mezo-, exo-, és makrorendszer. A modell alapján az egyén és a környezete egy rendszerben működik, amelyben a különböző szintek egymásra 
épülnek. „Az első a mikrorendszer, amely magában foglalja a gyereket és az őt körülvevő közvetlen környezetet. ... A mezorendszer két vagy több további színtér megjelenését jelenti a gyerek életében, amiben fejlődik a személyisége, aktivitása. Ilyen színtér a bölcsőde, óvoda, iskola, ami egyben a másodlagos szocializáció színtereként, hatással van a mikrorendszer működésére és viszont." (Rákó, 2014, 23.). Az exorendszert alkotják azok az intézmények, amelyek a gyermek mindennapi életére, fejlődésére indirekt módon hatnak. A makrorendszer alatt a világ működését meghatározó meggyőződéseket, elképzeléseket értjük. Ezek alapján töltik be az emberek a társadalmi szerepeket, illetve fogadják el az alapvető társadalmi normákat (N. Kollár és Szabó, 2004).

Bronfenbrenner modellje a gyermekotthonok mellett vonatkoztatható a javítóintézetekre is. A mikrorendszer esetében a nevelő és a növendék kapcsolatára, a napirendre, a csoportlégkörre. Ezen a szinten jelentős még a csoporttársakkal való kapcsolat minősége. A mezorendszer esetében az iskola és a munkafoglalkoztatási közösségre, szabadidős tevékenységekre vonatkoztatható. Az exorendszer esetében az intézmény intézményekkel meglévő kapcsolatára, illetve ide tartozik minden olyan személy, aki foglalkozik a növendékkel. Végül a makrorendszer esetében a beavatkozási eszközökre és intézményi szabályokra vonatkoztatva. Ehhez a szinthez tartoznak a nevelési módszerek, terápiás és csoportterápiás foglalkozások. Ide tartoznak az intézmény múködését meghatározó törvények is (Rákó, 2014).

\section{A kriminálpedagógiai alapelvek érvényesülése a javítóintézeti nevelés struktúrájában}

A következőkben annak érdekében, hogy átláthatóbbá váljon a javítóintézeti nevelés rendszere, röviden áttekintésre kerül a javítóintézet jogi háttere. A javítóintézeti nevelés a Büntető Törvénykönyvről szóló 2012. évi C. törvény 108.§ (1) bekezdés alapján bírói intézkedésnek felel meg. A törvény alapján a bíróság a fiatalkorú eredményes nevelése érdekében rendeli el, amely időtartalma minimum egy, maximum négy év. A javítóintézeti nevelési időtartam felénél, de legalább egy év után a bíróság dönthet az ideiglenes elbocsátásról.

A Gyvt. külön fejezetben rendelkezik a javítóintézeti nevelésről és ellátásról. A Gyvt. 66/M. § (1) - (3) bekezdése alapján az intézetek teljes körű ellátást biztosítanak a növendékek számára, és ellátják a fiatalkorú gondozását, nevelését, felügyeletét, továbbá az oktatásával, képzésével és munkafoglalkoztatásával kapcsolatos feladatokat. Az ellátását legfeljebb tizenkét fős csoportokban kell biztosítani (Gyvt. 66/M. § (1) - (3) bekezdés). Ugyan ezen törvény 66/N. § (1) bekezdése alapján a javítóintézet szervezeti felépítését és múködési rendjét a szervezeti és 
működési szabályzat határozza meg. A Gyvt. 66/O. § (1) - (4) bekezdés szerint a javítóintézeti tanács javaslatot tesz az igazgatónak a fiatalkorú zárt jellegű intézeti részlegben történő elhelyezésére, annak mellőzésére, megszüntetésére, vagy meghosszabbítására, illetve javaslatot tesz a fiatalkorú utógondozó részlegen való elhelyezésének engedélyezésére vagy annak elutasítására, továbbá javaslatot tesz a büntetés-végrehajtási bírónak a fiatalkorú ideiglenes elbocsátására vagy annak mellőzésére. A javítóintézeti utógondozást azok vehetik igénybe, akik a családjukba valamilyen oknál fogva nem térhetnek vissza, és az elbocsátás idejére nem sikerült számukra lakhatást és megélhetést teremteni, illetve ha a megkezdett tanulmányaikat a javítóintézeten belül szeretnék befejezni (D1). A Gyvt. 66/Q. § alapján a növendék az utógondozói részlegen a tanulmányainak befejezéséig, vagy élethelyzetének rendeződéséig, de legfeljebb 24. életévének betöltéséig maradhat.

Az előző fejezetben bemutatott javítóintézeti nevelésre kidolgozott modellek után a következőkben áttekintjük a javítóintézetek mûködését és pedagógiai programját. A javítóintézetek pedagógiai programja egységes szakmai sztenderdekre épül, amit 2015-ben egy szakmai munkacsoport dolgozott ki. A következőkben a „Társadalmi Megújulás Operatív Program Javítóintézeti ellátás biztosítása fiúk részére a Dunántúlon" című projekt keretében készült szakmai sztenderdeket mutatjuk be (D2, D3, D4, D5). Az intézetek a fiatalkorúak befogadása után többszintű ellátást biztosítanak számukra. Biztosítják a lakhatást 12-16 és 16-21 éves korcsoportbontásban. A tárgyi feltételt tekintve minden csoportnak külön biztosított a háló- és tanulószoba, közös nappali és fürdőszoba, továbbá az intézetek rendelkeznek többek között orvosi szobával, könyvtárral, szakköri helyiséggel, tornateremmel, sportpályával, terápiás csoportszobával.

Az alapvető szükségletek vonatkozásában biztosított számukra a napi ötszöri étkezés, évszaknak megfelelő ruházat, tisztálkodási eszközök, zsebpénz, illetve orvosi ellátás. A növendékek kapcsolatot tarthatnak a hozzátartozóikkal, védőjükkel, a pártfogó felügyelővel. A kapcsolattartás megvalósulhat látogatás, levelezés, csomagküldés, telefonbeszélgetés által.

A javítóintézet alapfeladata, hogy biztosítsa a bekerülő növendékek reszocializációját, ami alatt azt értjük, hogy igyekeznek megteremteni azokat a feltételeket és biztosítani azokat a körülményeket, amik hozzájárulnak a növendék társadalmi kirekesztődésének megszüntetéséhez. Alapvetően a nevelés módját két alapelvre fektetik le: a gyermeki jogok érvényre juttatására és egyénre szabott személyiségfejlesztésre. A pedagógiai folyamat - Volentics (1994) és Ruzsonyi (2002) által is kidolgozott - hét területre terjed ki, amelyek a következők: kulturáltsági szint emelése elsődlegesen oktatás segítségével; szocializációs folyamat diszfunkcióinak korrigálása, hiányosságok 
pótlása elsődlegesen életmód, életrend kialakításán keresztül. A munkavégzéshez szükséges képességek fejlesztése elsődlegesen munkafoglalkoztatás, szakmai oktatás, önkontroll fejlesztésének segítségével; viselkedés formálása elsősorban terápia, tréning, napi csoportfoglalkozások által; érzelmi élet fejlesztése elsősorban szorongások kezelésével, reális énkép kialakításával, szabadidő hasznos felhasználásával, nevelőkkel és társakkal kialakított kapcsolatokkal. Az erkölcsi fejlődés elősegítése leginkább tevékenységek rendszeres értékelésével, továbbá testi nevelés és egészséges életmód kialakítása sportfoglalkozások, és helyes életmód kialakítása által. A nevelés folyamatában törekednek a konstruktív életvezetés kialakítására. Ez alatt azt értjük, hogy olyan életvitelt igyekeznek kialakítani, amely szociálisan és az egyén szempontjából is értékes. Ezeket a tevékenységformákat a pozitív megerôsítéssel rögzítik a növendékben.

A javítóintézeti nevelés fontos eszköze az oktatási tevékenység. Az oktatás során igyekeznek a hiányzó ismereteket pótolni, tanulás iránti motivációt felkelteni, érdeklődési kört szélesíteni. Jellemző, hogy a fiatalok hosszú iskolakihagyás után kerülnek újra az iskolapadba, tudásuk sokszor nem adekvát a bizonyítványban szereplő eredményeknek, alacsony a tanulás iránti motivációjuk, írás, olvasási, számolási nehézségekkel küzdenek, saját képességeiket általában alulértékelik. A növendékek differenciált oktatásban részesülnek.
A meglévő tudást gyógypedagógus segítségével mérik fel, és egyéni oktatási tervet készítenek számukra, továbbá a növendékek fejlődésével kapcsolatban rendszeresen konzultálnak az érintett szakemberek. Az intézeteknek nagyon fontos feladata a munkafoglalkoztatás, a munkavégzéshez szükséges tudás átadása, hozzásegítés szakma megszerzéséhez, tehát a munkaerőpiacon történő elhelyezkedés esélyeinek növelése.

A javítóintézetek biztosítanak intézményen belüli, illetve intézményen kívüli munkafoglalkoztatást, amiért a növendékek díjazásban részesülnek. Az oktatáson és a munkafoglalkoztatáson kívül fontos a rekreációs lehetőségek biztosítása. Jellemző a növendékekre, hogy szabadidejüket nem tudják hasznosan tölteni, mivel a szabadidős tevékenységekkel kapcsolatban kevés ismerettel rendelkeznek, ezért az intézeteknek egyik alapvető feladata, hogy olyan rekreációs tevékenységekkel ismertessék meg a fiatalokat, amiket az intézet után is szívesen végeznek.

Mindezek alapján elmondhatjuk, hogy a javítóintézet semmiképp sem büntető jellegű, hanem teljes mértékben a növendék fejlődését, társadalmi reintegrációját szolgálja (D2, D3, D4, D5). Magyarországon minden intézmény ezen protokoll alapján működik. A fentiekből kifolyólag látható, hogy Volentics (1994, 1996), illetve Ruzsonyi (2002, 2008) által megfogalmazott nevelési, fejlesztési területek, célok egyaránt megjelennek a javítóintézeti nevelés szakmai programjában. 
A továbbiakban az 1. táblázat segítségével tekintjük át azt, hogy a pedagógiai folyamat hét területéhez hogyan tudnak kapcsolódni a növendékek nevelésével foglalkozó különböző szakemberek.

\section{1. táblázat: A pedagógiai folyamat hét területe a növendékek nevelését végző szakemberekre} vonatkoztatua. Forrás: a Szerzö

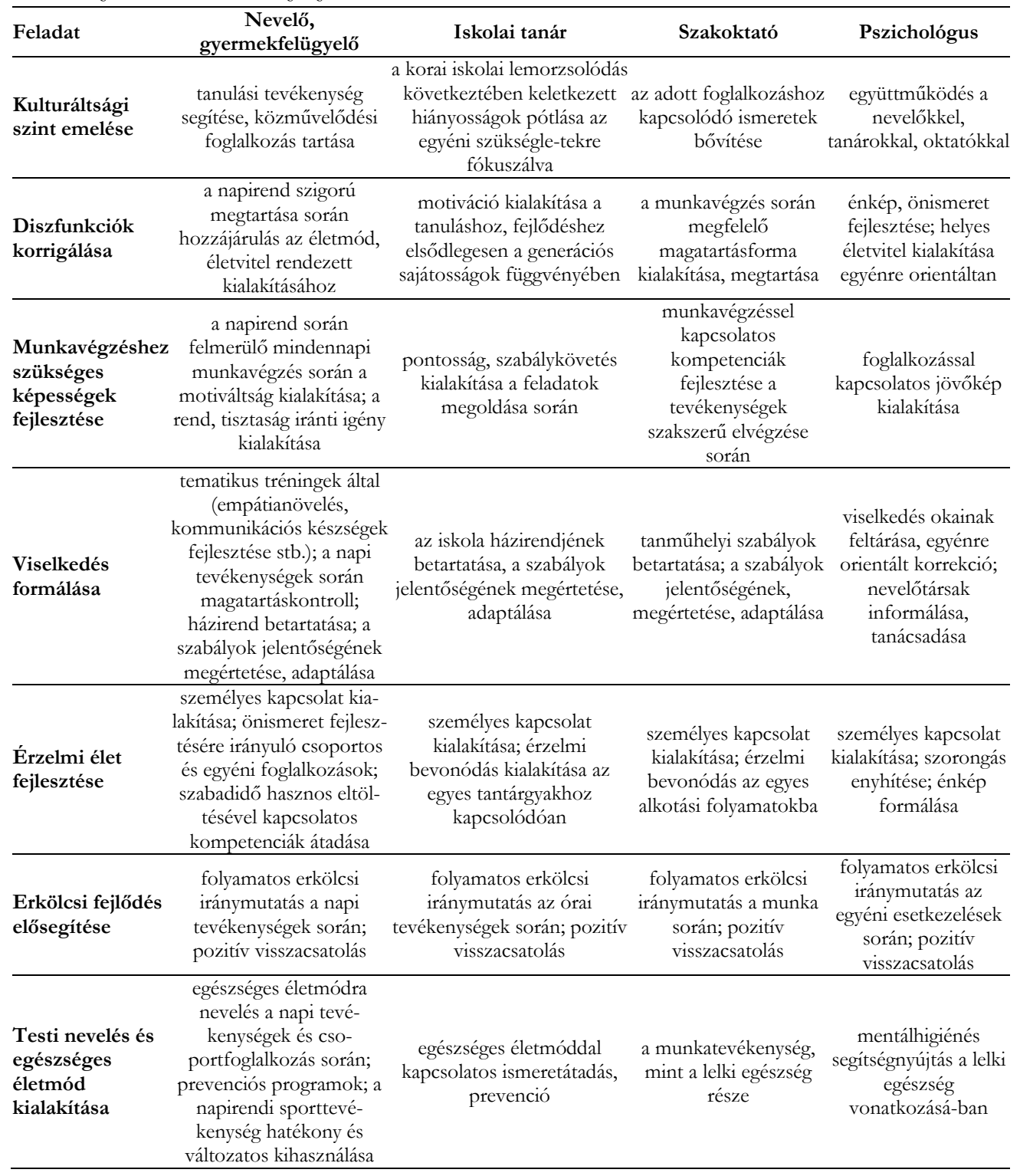


Az 1. táblázatban láthatjuk, hogy a szakemberek feladatköre valamennyi területre kiterjed, a különböző feladatok fedhetik egymást, illetve számos más tevékenységekkel kiegészülnek. A pedagógusok elsődlegesen csoportszinten végzik a feladatokat, míg a pszichológus számára leginkább az egyéni esetkezelés útján valósulnak meg a nevelési célok.

Felmerül a kérdés, hogy milyen eredményeket tud felmutatni a javítóintézet, mi történik az elbocsájtás után. Az utánkövetésnek számos nehézsége van, mivel a javítóintézet „,nem hagy nyomot” maga után. Ideiglenes elbocsátás esetén a növendék pártfogás alatt áll, de amint letelik az ideiglenes elbocsátás tartalma, a fiatal kikerül a látókörből. Hatvani Erzsébet és Papházi Tibor (2003) szerint a javítóintézet utáni életutak sokszínűek lehetnek, de mégis tipizálhatóak. Konkrét típusneveket nem fogalmaznak meg, de háromféle utóéletet különböztetnek meg és írnak le. Az első típus azon volt növendékek csoportja, akiknek az élete pozitív irányt vett fel, sikeresen reintegrálódtak, illetve voltak, akik mobilizálódtak is. A második típusba azok tartoznak, akik nem lettek visszaesők, de életükben számos nehézség van jelen. A harmadik típusba pedig azok a volt növedékek tartoznak, akik visszaesők lettek tehát újabb bűncselekményt követtek el (Hatvani és Papházi, 2003).

A javítóintézetekben dolgozó szakemberek növendékközpontú tevékenységük során igyekeznek biztosítani a reinteg- rációt, illetve növelni a mobilizációs esélyeket. A nevelés és a napi tevékenységes során olyan alternatívákat nyújtanak a fiataloknak, amik a többség esetében az addigi életük során nem volt jelen, de a szocializáció szempontjából elengedhetetlenül fontosak.

\section{A javítóintézeti nevelés}

\section{folyamatát vizsgáló kutatás háttere}

A kutatásunk az EMMI Debreceni Javítóintézetében fog megvalósulni. A kutatás során kvalitatív (félig strukturált interjú) és kvantitatív (dokumentumelemzés) módszerekkel igyekszünk vizsgálni a javítóintézeti nevelés eredményességét, egyrészt a növendékek tapasztalatai, másrészt a nevelők, tanárok, pszichológus tapasztalatai, harmadrészt a növendékek dokumentumai alapján. A kutatás fő célja, hogy a növendékek intézetben töltött éveit olyan módon vizsgáljuk, ami alapján mérni, és tipizálni tudjuk a nevelés hatékonyságát. Ennek érdekében elemezzük a növendékeket saját meglátásuk, és nevelőik szempontja alapján. A növendékek esetén a minta 13 fő javítóintézeti növendék, akik legalább egy éve intézeti nevelésben részesülnek, és betöltötték 16 . életévüket. A nevelők esetén nyolc fő javítóintézeti nevelő (ebből két fő befogadó csoportnevelő), a tanárok, szakoktatók vonatkozásában három fő javítóintézeti tanár, és egy fő tanműhely oktató, továbbá egy fő pszichológus.

A kutatási kérdések a következők: 
1. Milyen jellemzőkkel rendelkeznek a növendékek, amikor az intézetbe kerülnek, különös tekintettel a mindennapi életvitelre, tanulásra, magatartásra, pszichés állapotra, személyiségre, munkához való hozzáállásra vonatkoztatva?

2. Mik a legfőbb nehézségek a nevelési folyamat során? Hogyan kezelik ezeket a különböző szakemberek?

3. Minimum egy év javítóintézeti nevelés után, milyen változások következnek be a mindennapi életvitelre vonatkozóan?

4. Minimum egy év javítóintézeti nevelés után, milyen változások következnek be a tanulásra, munkára vonatkozóan?

5. Minimum egy év javítóintézeti nevelés után, milyen változások következnek be a pszichés állapotra, és személyiségre vonatkozóan?

6. Minimum egy év javítóintézeti nevelés után, milyen jövőbeli kilátásokat látnak a szakemberek és a növendékek?

7. Milyen módszerekkel érik el a változást a különböző szakemberek?

A dokumentumelemzés tekintetében minden növendék esetén háromhavonta van felülvizsgálat, ebből kifolyólag a növendék-minta fejenként rendelkezik legalább négy felülvizsgálattal, így minimum összesen 60 felülvizsgálati dokumentum kerül áttekintésre a következő szempontok alapján: nevelő meglátásai, célkitűzés; iskola meglátása, célkitűzés; szakoktató meglátásai, célkitűzés; pszichológus meglátásai, célkitűzés; egészségügyi részleg meglátásai, célkitűzés.

A szakemberek leírásai alapján elsődlegesen a legkorábbi és legutóbbi leírás vonatkozásában vizsgáljuk a növendékminta változásait, hogy pozitív, negatív vagy stagnál, történt-e fejlődés, vagy visszafejlődés, illetve milyen területeken. Áttekintésre kerül a személyi lap, ami tartalmazza a jutalmakat, büntetéseket. Ez esetben a jutalmak és büntetések alakulásának számát, és időbeli eloszlását vesszük figyelembe.

\section{Irodalom}

Maslow, A. (1970): Motivation and Personality (2nd edition). New York: Harper and Row.

Bábosik István (1987): Jellemformálás és jellemfejlōdés. Tankönyvkiadó, Budapest. Bronfenbrenner, U. (1992): Ecological systems theory. In Vasta, R. (Ed.), Six theories of child development: Revised formulations and current issues. Jessica Kingsley Publishers, London.187-249.

Hatvani E. és Papházi T. (2003): A javítóintézet utáni életutak. Kapocs, 2. 5. 56-68.

Korinek L. és Lévay M. (2006): A kriminológia fogalma, feladata, kutatási területe. In: Gönczöl K., Kerezsi K., Korinek L. és Lévay M. (szerk.): Kriminológia - Szakekriminológia. Complex Kiadó, Budapest.

N. Kollár K. és Szabó É. (2004): Pszichológia pedagógusoknak. Osiris Kiadó, Budapest. 
Rákó E. (2014): Gyermekvédelmi intézményekben elhelyezett gyerekek életkörülményei. Belvedere Meridionale, Szeged.

Ruzsonyi P. (2002): Karakteresen eltérő kezelési formák a fiatalkorú fogvatartottak körében. Börtönügyi Szemle, 21. 2. 23-52.

Ruzsonyi P. (2006): A kriminálpedagógia lehetősége a börtönadaptáció és a társadalmi integrálódás érdekében. Börtönügyi Szemle, 25. 2. 21-33.

Ruzsonyi P. (2008): Kriminálpedagógiai útkeresés a fiatalkorú fogvatartottak szabadságvesztés- büntetésének végrehajtásában. Börtönügyi Szemle, 27. 4. 1432.

Volentics A. (1994): Elképzelések a fiatalkorú zárt intézeti neveltek reszocializációs gondozásának korszerúsítéséről. In: Gönczöl K. (szerk.): Büntetópolitika, bünmegelózés, ELTE Szociológiai Intézet Szociálpolitikai Tanszéke, Budapest. 151-169.

Volentics A. (1996): Gyermekvédelem és reszocializáció. Nemzeti Tankönyvkiadó, Budapest.

\section{Jogszabályok}

1997. évi XXXI. törvény a gyermekek védelmérôl és a gyámügyi igazgatásról

2012. évi C. törvény a Büntetô Törvénykönyvről

2013. évi CCXL. törvény a büntetések, az intézkedések, egyes kényszerintézkedések és a szabálysértési elzárás végrehajtásáról

\section{Dokumentumok}

D1: Emberi Erőforrások Minisztériuma

Debreceni Javítóintézete és Emberi

Erőforrások Minisztériuma Debrecen

Javítóintézete Nagykanizsai

Telephelye, Szakmai Program 2018.

Letöltés: 2018.11.02. Web:

http://www.dji.hu/Szakmai_tev/doku mentum/SZAKMAI_PROGRAM_20 18.pdf

D2: Bevezetó gondolatok a javitóintézeti nevelés tanulmányaihoz: Letöltés: 2017.12.10. Web: http://www.dji.hu/Szakmai_tev /Standardizalas_dokumentumai/1_A_ javitointezetek_egyuttmukodese.pdf

D3: Hatvani E., Juhász P. és Zámbori T.: A bünmegelórés és bünismétlés meg-elórését szolgáló szakmai tevékeny-ségek, tartalmak, ismert/ bevált jó gya-korlatok hasznositása és a javitó-intézetben történö alkalmazásnak elemző viasgálata (elterelés, jóvátétel). A vizsgálat eredmény ismeretében a lehetséges fejlesztési irányok, az ehhez szülkséges személyi és tárgyi feltételek meghatározása, a szülkségesnek itélt jogszabály módositások megfogalma-zása. Letöltés: 2017.12.10. Web: http://www.dji.hu/Szakmai_tev /Standardizalas_dokumentumai/4_A_ kriminalizalodas_megelozesere_szolgal o_\%20javaslatok_es_feltetelek_javitoi ntezetben.pdf (2017.12.10)

D4: Antal G., Hegedűs S., Puskás P., Szabó P. és Szim A.: A szakmai program egyéni szintre történó lebontásáboz, egyéni szinten történö megvalósitásához és értékeléséhez, szülkséges tevékenységrendszer kidolgozása és adminisztrációs kereteinek megha- 
tározása. Letöltés 2017.12.10. Web: http://www.dji.hu/Szakmai_tev/Stan dardizalas_dokumentumai/8_A_szak mai_program_vegrehajtasahoz_szukse ges_dokumentumrendszer.pdf

D5: Antal G., Hegedűs S., Puskás P., Szabó P. és Szim A.: A javitóintézeti feladatellátás szakmai folyamatainak beazonositása, leírása folyamatában történö megjelenitése, protokolljainak, tevékenység admi- nisztrációjának kidolgozása, az e tevékenységekre alapozott esetleges jogszabály módositási javaslatok megfogalmazása, mindezeknek a standardizációs anyagban történó rögzitése. Letöltés 2017.12.10. Web: http://www.dji.hu/Szakmai_tev/Stan dardizalas_dokumentumai/9_A_javito intezeti_szakmai_tevekenyseg_standar djai.pdf 